\title{
PENGARUH PUPUK SP-36 DAN PUPUK BIO-URIN SAPI TERHADAP PERTUMBUHAN DAN HASIL TANAMAN TERONG HIJAU (Solanum melongena L.) VARIETAS ARYA HIJAU
}

\author{
Amanda Oktaviani ${ }^{1}$ \\ ${ }^{1}$ Agroteknologi, Fakultas Pertanian, Universitas 17 Agustus 1945 Samarinda 75124, \\ Indonesia. \\ Jl. Ir. H. Juanda No.80 Samarinda, 75124, Indonesia. \\ E-Mail: amandaoktaviani81@yahoo.co.id
}

\begin{abstract}
ABSTRAK
Pengaruh Pupuk SP-36 dan Pupuk Bio-Urine Sapi Terhadap Pertumbuhan dan Hasil Tanaman Terong Hijau (Solanum melongena L.) Varietas Arya Hijau. Tujuan penelitian untuk mengetahui pengaruh pupuk sp-36 dan pupuk bio-urine sapi serta interaksinya terhadap pertumbuhan dan hasil tanaman terong hijau, serta untuk mengetahui dosis pupuk sp-36 dan pupuk bio urine sapi yang tepat untuk menghasilkan tanaman terong yang bagus.

Penelitian menggunakan Rancangan Acak Lengkap (RAL), dalam percobaan factorial 4x4, dengan 4 ulangan. Terdiri atas 2 faktor perlakuan. Factor I adalah pupuk SP-36 (S), terdiri atas 4 taraf. Faktor II adalah pupuk bio-urine sapi (B), terdiri atas 4 taraf

Hasil penelitian menunjukkan bahwa perlakuan pupuk SP-36 (S) sangat berpengaruh nyata terhadap tinggi tanaman umur 15, 30 dah 45 hari setelah tanam, umur saat berbunga, umur panen, jumlah buah pertanaman, dan berat buah per tanaman. Berat buah terong tertinggi terdapat pada perlakuan $\mathrm{s}_{3}$ pupuk SP-36, yaitu 1,81 $\mathrm{kg} /$ tanaman, sedangkan yang terendah terdapat pada perlakuan $\mathrm{s}_{0}$, yaitu $1,52 \mathrm{~kg} /$ tanaman.

Perlakuan pupuk SP-36 (S) sangat berpengaruh nyata terhadap tinggi tanaman umur 15, 30 dah 45 hari setelah tanam, umur saat berbunga, umur panen, jumlah buah pertanaman, dan berat buah per tanaman. Berat buah terong tertinggi terdapat pada perlakuan $\mathrm{s}_{3}(\mathrm{SP}-36)$, yaitu 1,81 kg/tanaman, sedangkan yang terendah terdapat pada perlakuan $\mathrm{s}_{0}$, yaitu $1,58 \mathrm{~kg} /$ tanaman.

Perlakuan pupuk bio-urine sapi (B) sangat berpengaruh nyata terhadap tinggi tanaman umur 15, 30 dah 45 hari setelah tanam, umur saat berbunga, umur panen, jumlah buah pertanaman, dan berat buah per tanaman. Berat buah terong tertinggi terdapat pada perlakuan $b_{3}$ (bio-urine sapi), yaitu 2,04 kg/tanaman, sedangkan yang terendah terdapat pada perlakuan $\mathrm{b}_{0}$, yaitu $1,14 \mathrm{~kg} /$ tanaman.

Interaksi perlakuan $(\mathrm{SxB})$ sangat berpengaruh nyata terhadap tinggi tanaman umur 15, 30 dah 45 hari setelah tanam, umur saat berbunga, umur panen, jumlah buah pertanaman, dan berat buah per tanaman.
\end{abstract}

Kata kunci : Pertumbuhan, Pupuk Bio-Uirine, Pupuk SP-36, Terong hijau.

\begin{abstract}
Effect of SP-36 Fertilizer and Cattle Bio-Urine Fertilizer on the Growth and Yield of Green Eggplant Plants (Solanum melongena L.) Green Aryan Variety. The purpose of the study was to determine the effect of SP-36 fertilizer and cattle bio-urine fertilizer and their interaction on the growth and yield of green eggplant plants, as well as to determine the proper dosage of those fertilizers to produce good eggplant plants.

The study used a Completely Randomized Design (CRD), in a factorial $4 x 4$ experiment, with 4 replications. It consists of 2 treatment factors. Factor I is SP-36 (S) fertilizer, consisting of 4 levels. The second factor is cattle bio-urine fertilizer (B), consisting of 4 levels.

The results showed that SP-36 (S) fertilizer treatment had a significant effect on the plant height at aged 15-, 30- and 45-days after planting, age of plant flowered, age of plant harvested, number of fruit per plant, and weight of fruit per plant. The highest weight of eggplant fruit was found in SP-36 fertilizer treatment, which is $1.81 \mathrm{~kg} /$ plant, while the lowest one is in the treatment of $s_{0}$, which is $1.52 \mathrm{~kg} /$ plant.

The treatment of SP-36 fertilizer (S) had significant effect on the height of plants at aged 15-, 30- and 45days after planting, age at plant flowered, age of plant harvested, number of fruit per plant, and weight of
\end{abstract}


fruit per plant. The highest weight of eggplant fruit was found in treatment $S_{3}$, which was $1.81 \mathrm{~kg} / \mathrm{plant}$, while the lowest was in treatment $S_{0}$, which was $1.58 \mathrm{~kg} / \mathrm{plant}$.

The treatment of cattle bio-urine fertilizer $(B)$ had significant effect on the height of plants at aged 15-, 30and 45-days after planting, age of plant flowered, age of plant harvested, number of fruit per plant, and weight of fruit per plant. The highest weight of eggplant was found in $b_{3}$ treatment, which was $2.04 \mathrm{~kg} / \mathrm{plant}$, while the lowest one was in treatment $b_{0}$, which was $1.14 \mathrm{~kg} / \mathrm{plant}$.

Treatment interaction (SxB) had significant effect on the plant height at aged 15-, 30- and 45-days after planting, age of plant flowered, age of plant harvested, number of fruit per plant, and weight of fruit per plant.

Key words : Cattle Bio-Urine Fertilizer, Green Eggplant, Growth, SP-36 Fertilizer.

\section{PENDAHULUAN}

Terong (Solanum melongena L.) banyak dibudidayakan diberbagai wilayah di Indonesia. Terong merupakan jenis sayuran yang mampu berproduksi hingga dua tahun dan memiliki nilai produktivitas yang cukup tinggi. Karena itu terong menjadi salah satu jenis sayuran memiliki prospek yang menjanjikan. Harga terong yang relatif stabil, bisa menjadi pertimbangan untuk membudidayakan secara luas.

Iritani (2012) menyebutkan bahwa terong diketahui memiliki zat anti kanker, kandungan tripsin (protease) yang terkandung pada terong merupakan inhibitor yang dapat melawan zat pemicu kanker. Jus terong yang dikonsumsi secara rutin dapat membantu mengatasi kerusakan yang terjadi pada sel yang mengalami kerusakan kromosom (terkena kanker). Mengingat banyaknya manfaat buah terong dan meningkatnya permintaan terong, maka perlu diadakan penelitian lebih mendalam mengenai komoditas terong sehingga mampu meningkatkan kualitas ekonomi petani. Tanaman terong memiliki rasa yang enak dan mengandung zat gizi yang bermanfaat bagi manusia. Tanaman ini mengandung protein, lemak, karbohidrat vitamin $\mathrm{A}$, vitamin $\mathrm{B}$, vitamin $\mathrm{C}$, kalsium, fosfor serta zat besi.

Semakin banyaknya masyarakat yang mengetahui manfaat terong khususnya terong hijau, permintaan terhadap terong terus meningkat sejalan dengan pertambahan penduduk yang diikuti dengan meningkatnya kesadaran akan manfaat sayur-sayuran dalam memenuhi gizi keluarga, sehingga produksi tanaman terong perlu terus ditingkatkan. Untuk meningkatkan produksi tanaman terong dapat dilakukan secara ekstensifikasi dan intensifikasi, namun dalam usaha peningkatan produktivitas dan efisiensi penggunaan tanah, cara intensifikasi merupakan pilihan yang tepat untuk diterapkan. Salah satu usaha tersebut dengan pemberian pupuk anorganik pupuk organik.

Pupuk anorganik SP-36 merupakan pupuk tunggal dengan kandungan Phosphor (P) cukup tinggi dalam bentuk $\mathrm{P}_{2} \mathrm{O}_{5}$, yakni sebesar 36\%. Pupuk SP-36 dapat digunakan sebagai pupuk dasar maupun pupuk susulan pada masa pertumbuhan tanaman terong. SP-36 sering digunakan untuk berbagai jenis tanaman, baik tanaman pangan, holtikultura maupun tanaman perkebunan.

Selain pupuk anorganik, pupuk organik juga baik digunakan sebagai sumber unsur hara untuk pertumbuhan tanaman terong hijau, salah satunya yaitu limbah cair kotoran ternak dari usaha peternakan sapi yang menghasilkan limbah yang berupa kotoran sapi (feses) dan air seni sapi (urine). Limbah tersebut dapat dijadikan pupuk organik dalam pertanian, dapat mengembalikan unsur hara dalam tanah dan mengurangi pemakaian pestisida. Limbah padat 
(feses) dapat diolah menjadi pupuk kompos dan limbah cair (urine) dapat juga diolah menjadi pupuk organik cair.

Pupuk organik cair merupakan dekomposisi bahan - bahan organik atau proses perombakan senyawa yang kompleks menjadi senyawa yang sederhana dengan bantuan mikroorganisme. Urin sapi memiliki kandungan hara makro nitrogen $0,52 \%$, fosfor $0,01 \%$, dan kalium $0,56 \%$, di samping itu kotoran sapi merupakan kotoran ternak yang baik untuk kompos (Hadisuwito, 2012).

Urin sapi dapat diolah menjadi pupuk organik cair. Sebelum digunakan sebagai pupuk pertanian, urin sapi ini sebaiknya difermentasi terlebih dahulu. Pada proses fermentasi urin sapi, menggunakan bantuan bakteri dekomposer atau bioaktivator seperti EM4 (Effective Microorganisme). Menurut Setiawan (2010), kandungan EM4 (Effective Microorganism) tersebut adalah mikroorganisme Lactobacillus sp., bakteri penghasil asam laktat, serta dalam jumlah sedikit bakteri fotosintetik Streptomyces sp. dan ragi.

$\begin{array}{ccc}\text { Kultur } & \text { campuran } & \text { dari } \\ \text { mikroorganisme } & \text { yang } & \text { mampu }\end{array}$ mempercepat proses pengomposan. Jumlah dan jenis mikroorganime juga mempengaruhi proses pengomposan. Dari berbagai penelitian banyak yang menggunakan EM4 (Effective Microorganism). Affandi (2008) mengatakan bahwa, dalam pembuatan pupuk urin sapi (pupuk cair) pada proses fermentasi menggunakan EM4 (Effective Microorganisme) 1 liter ke dalam 100 liter urin sapi. Setelah kurang dari 7 hari pupuk urin sapi telah dapat digunakan dengan indikator pupuk urin terlihat kehitaman.

Pendapat selanjutnya menurut Rahayu dan Nurhayati (2005) bahwa, penggunaan EM4 (Effective Microorganism) dapat memepengaruhi pengomposan, hal itu dapat dilihat dari perlakuan lama pengomposan nyata meningkatkan $\mathrm{N}$-total, $\mathrm{P}, \mathrm{K}$, dan $\mathrm{Mg}$, serta menurunkan suhu, C-organik dan nisbah $\mathrm{C} / \mathrm{N}$ kompos. Sedangkan unsur mikro cenderung meningkat dan $\mathrm{pH}$ cenderung menurun dengan semakin lama pengomposan. Pengomposan selama 15 hari dapat menghasilkan kualitas tidak berbeda nyata dengan lama pengomposan selama 20 hari.

Berdasarkan uraian tersebut penulis telah melakukan penelitian dengan judul "Pengaruh Pupuk SP-36 dan Pupuk BioUrine Sapi Terhadap Pertumbuhan dan Hasil Tanaman Terong Hijau (Solanum melongena L.) Varietas Arya Hijau. Tujuan penelitian adalah untuk mengetahui pengaruh Pupuk SP-36 dan Pupuk Bio-Urine Sapi serta interaksinya terhadap pertumbuhan dan hasil tanaman terong hijau (Solanum melongena L.) Varietas Arya Hijau. Untuk mengetahui dosis Pupuk SP-36 dan konsentrasi Pupuk Bio-Urine Sapi yang tepat untuk pertumbuhan dan hasil terong hijau Varietas Arya Hijau yang terbaik.

\section{METODA PENELITIAN}

\subsection{Tempat dan Waktu}

Penelitian dilaksanakan di Kelurahan Sempaja Utara Kecamatan Samarinda Utara. Pada bulan MaretJuni 2018.

\subsection{Bahan dan Alat}

Bahan yang digunakan adalah Benih tanaman Terong Hijau (Solanum Lycopersicum L.). Varietas Arya Hijau, media tanam berupa top soil, pupuk SP-36, pupuk organik BioUrine sapi, air dan turus/bambu. Sedangkan alat yang digunakan cangkul, bak persemaian, polybag, paranet, label unit percobaan, tali raffia, hand sprayer kecil, ember, gayung, meteran, alat tulis dan kamera. 


\subsection{Rancangan Penelitian}

Penelitian menggunakan Rancangan Acak Lengkap (RAL) dalam percobaan faktorial $4 \times 4$, dengan dua faktor perlakuan, diulang sebanyak 4 kali. Faktor I : Dosis Pupuk SP-36 (S) yang terdiri dari 3 taraf dengan dosis: $\mathrm{s}_{0}$ : tanpa pemberian pupuk SP-36 (sebagai kontrol)

$\mathrm{s}_{1}$ : dosis pupuk SP-36 0,2 ton/ha setara 12,8 $\mathrm{g}$ tanaman $^{-1}$

$\mathrm{s}_{2}$ : dosis Pupuk SP-36 0,3 ton/ha setara 19,2 g tanaman $^{-1}$

$\mathrm{s}_{3}$ : dosis pupuk SP-36 0,4 ton/ha setara 25,6 $\mathrm{g} \operatorname{tanaman}^{-1}$

Faktor I : Konsentrasi Pupuk Organik Bio-Urine Sapi (B) yang terdiri dari 4 taraf dengan dosis:

$\mathrm{b}_{0}$ : tanpa pupuk organik bio-urine ( sebagai kontrol )

$b_{1}$ : konsentrasi pupuk organik biourine $54 \mathrm{ml}^{\text {tanaman }}{ }^{-1}$

$\mathrm{b}_{2}$ : konsentrasi pupuk organik biourine $64 \mathrm{ml}^{\text {tanaman }}{ }^{-1}$

$b_{3}$ : konsentrasi pupuk organik biourine $74 \mathrm{ml} \mathrm{tanaman}^{-1}$

$\begin{array}{llll}\mathrm{s}_{0} \mathrm{~b}_{0} & \mathrm{~s}_{0} \mathrm{~b}_{1} & \mathrm{~s}_{0} \mathrm{~b}_{2} & 0 \mathrm{~b}_{3} \\ \mathrm{~s}_{1} \mathrm{~b}_{0} & \mathrm{~s}_{1} \mathrm{~b}_{1} & \mathrm{~s}_{1} \mathrm{~b}_{2} & \mathrm{~s}_{1} \mathrm{~b}_{3} \\ \mathrm{~s}_{2} \mathrm{~b}_{0} & \mathrm{~s}_{2} \mathrm{~b}_{1} & \mathrm{~s}_{2} \mathrm{~b}_{2} & \mathrm{~s}_{2} \mathrm{~b}_{3} \\ \mathrm{~s}_{3} \mathrm{~b}_{0} & \mathrm{~s}_{3} \mathrm{~b}_{1} & \mathrm{~s}_{3} \mathrm{~b}_{2} & \mathrm{~s}_{3} \mathrm{~b}_{3}\end{array}$

\subsection{Prosedur Pelaksanaan Penelitian}

\section{Penyemaian Benih}

Benih tanaman terong yang akan disemai merupakan benih yang berasal dari benih hibrida (benih yang bermutu). Benih terong disemai pada petak atau trai semai yang telah disiapkan, dengan ukuran 2,3 x 2,3cm jarak antar lubang semai. Media dipersemaian merupakan campuran tanah top soil dan pupuk kandang sapi dengan perbandingan 1:1. Bila bibit terong dipersemaian telah berdaun 3 atau 4 helai, maka segera pindah ke media tanam di polibag yang telah disiapkan sebelumnya.
Persiapan Media Tanam

a. Pembuatan media tanam

Tanah yang dijadikan media tanam adalah tanah top soil, yang diambil disekitar tempat penelitian. Tanah dicampur jadi satu, dicampurkan secara merata, kemudian dipisahkan dari kotoran seperti rumput, akar, kayu, dan lainnya dengan tujuan untuk memperoleh tanah yang seragam dan bebas dari kotoran lainnya. Tanah yang telah dicampur tersebut kemudian ditambahkan pestisida furadan $3 \mathrm{G}$ dan dibiarkan selama 3 hari.

b. Pengisian Tanah di Polibag

Tanah top soil yang telah dicampurkan dengan Furadan 3 G tersebut kemudian dimasukan kedalam polibag dengan ukuran $30 \mathrm{~cm}$ x $40 \mathrm{~cm}$ dengan berat tanah $10 \mathrm{~kg}$. Jumlah polibag yang dipersiapkan untuk diisi media tanam berjumlah 64 polibag. Kemudian polibag disusun di lokasi penelitian sesuai dengan tata letak yang telah diacak.

Pemindahan Bibit di Polibag

Setelah bibit tomat berdaun 4 helai (umur 2 minggu setelah persemaian), dilakukan pemindahan bibit dengan cara membuat lubang tanam pada media tanam dalam polibag. Tiap polibag ditanam 1 (satu) bibit yang sehat dan seragam (tinggi dan jumlah daun).

Pemberian Pupuk SP-36

Pemberian pupuk dilakukan sesuai perlakuan yaitu, 30 Hari setelah tanam, diberikan pupuk SP-36 atau control $\left(\mathrm{p}_{0}\right)$, dosis pupuk 12,8 g tanaman ${ }^{1}\left(\mathrm{p}^{1}\right)$, dosis pupuk 19,2 g tanaman ${ }^{-1}\left(\mathrm{p}^{2}\right)$. Pemberiannya dilakukan sekali saja dengan cara disebar di permukaan tanah secara merata.

Pemberian Pupuk Bio-Urine Sapi 
Pupuk Bio Urine Sapi diberikan sesuai dengan konsentrasi perlakuan yaitu: tanpa pupuk Bio Urine Sapi $\left(b_{0}\right)$, konsentrasi pupuk Bio-Urine Sapi $25 \mathrm{ml}$ $\operatorname{tanaman}^{-1}\left(\mathrm{~b}_{1}\right)$, konsentrasi pupuk BioUrine Sapi $50 \mathrm{ml} \operatorname{tanaman}^{-1}\left(\mathrm{~b}_{2}\right)$, dan konsentrasi pupuk Bio-Urine Sapi $75 \mathrm{ml}$ tanaman $^{-1}$. Pemberian 7 hari setelah tanam dengan cara disemprotkan pada bagian tanaman, terutama bagian daun bagian bawah dan atas, Dilakukan pagi hari sekitar jam 09.00-10.00 wita.

Pemeliharaan

c. Penyiraman

Penyiraman dilakukan dua kali sehari pagi dan sore hari.

d. Penyulaman

Penyulaman dilakukan apabila ada benih yang tidak tumbuh atau bibit yang mati. Penyulaman dilakukan pada saaat tanaman berumur 7 hari setelah tanam. Bibit untuk penyulaman telah disiapkan sebanyak 16 polibag.

e. Penyiangan

Penyiangan dilakukan setiap saat bila ada gulma yang tumbuh, baik di dalam polibag maupun di luar polibag.

f. Pengendalian hama dan penyakit

Pengendalian hama dan penyakit yang dilakukan pada gangguan penyakit yaitu, yang disebabkan oleh jamur. Pengendalian dilakukan dengan fungisida Dithane M-45 dan Marshal dengan dosis $2 \mathrm{~g} /$ liter air.

\section{Panen}

Tanaman terong dipanen umur \pm 60 hari setelah tanam. Kriteria panen buah terong layak panen adalah daging belum keras, warna buah mengkilat, ukuran tidak terlalu besar ataupun terlalu kecil. Pemanenan dilakukan sebanyak 4 kali, dengan interval panen 7-8 hari sekali.

\subsection{Pengamatan}

Pada penelitian ini pengamatan yang dilakukan adalah melihat pengaruh Pupuk Pupuk SP-36 dan Pupuk BioUrine Sapi terhadap pertumbuhan dan hasil tanaman terong, yaitu:

Tinggi tanaman $(\mathrm{cm})$

Pengukuran tinggi tanaman dilakukan mulai dari pangkal batang yang telah diberi tanda permanen (dengan spidol) sampai ujung titik tumbuh pada umur 15 hari, 30 hari dan 45 hari setelah tanam.

Umur saat berbunga (hari)

Dihitung sejak mulai bibit dipindah kedalam polibag sampai dengan munculnya bunga pertama kali.

Umur panen (hari)

Umur panen dihitung sejak pertama kali dipindah ke dalam polibag sampai dengan buah dipanen pertama kali. Jumlah buah per tanaman (buah)

Dihitung jumlah buah per tanaman setiap panen dan dijumlahkan sampai 4 kali panen.

Berat buah per tanaman $(\mathrm{kg})$

Dengan menimbang berat buah segar per tanaman pada setiap kali panen dan dijumlahkan beratnya, dari panen pertama sampai panen ke-empat.

\subsection{Analisis Data}

Untuk mengetahui pengaruh perlakuan pupuk SP-36 dan BioUrine Sapi serta interaksinya terhadap pertumbuhan dan hasil tanaman terong hijau varietas Arya Hijau maka dilakukan dengan menganalisis data dengan sidik ragam. Adapun model sidik ragam yang digunakan menurut Yitnosumarto (1991).

Bila hasil sidik ragam terhadap perlakuan tidak berpengaruh nyata (non signifikan) yang menunjukkan dimana $\mathrm{F}$ hitung $\leq \mathrm{F}$ table 0,05 maka 
tidak dilanjutkan uji lanjutan, tetapi bila hasil sidik ragam terhadap perlakuan berpengaruh nyata (signifikan) yang menunjukkan dimana $\mathrm{F}$ hitung > Ftabel 0,05 atau berpengaruh sangat nyata yang menunjukkan $\mathrm{F}$ hitung $>\mathrm{F}$ table 0,01 , maka untuk membandingkan dua rata-rata perlakuan, dilakukan uji Beda Nyata Terkecil (BNT) taraf 5\%. Rumus uji BNT disajikan sebagai berikut :

$$
\text { BNT 5\% = t-tabel }(\mathrm{a}, \mathrm{db}) \times \sqrt{2} \mathrm{KT} \text { galat } / \mathrm{r}
$$

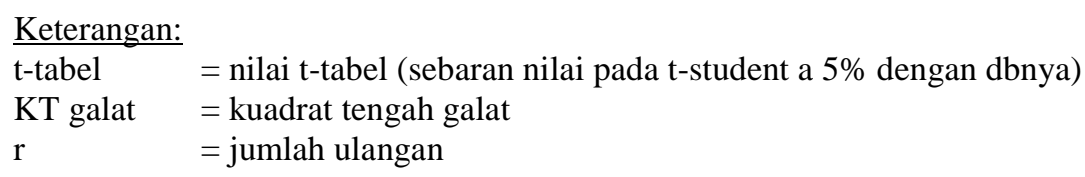

\section{HASIL PENELITIAN DAN PEMBAHASAN}

\subsection{Tinggi Tanaman $(\mathrm{cm})$}

\section{Tinggi Tanaman Umur 15 Hari Setelah} Tanam

Hasil sidik ragam menunjukkan bahwa perlakuan pupuk SP-36 (S) dan pupuk bio-urine sapi (B) serta interaksinya $(\mathrm{SxB})$ berpengaruh sangat nyata terhadap tinggi tanaman umur 15 hari setelah tanam

Hasil uji BNT taraf 5\% pada perlakuan pupuk SP-36 (S) terhadap tinggi tanaman umur 15 hari setelah tanam menunjukkan bahwa perlakuan $s_{3}$ berbeda nyata dengan perlakuan $s_{2}$ dan perlakuan $\mathrm{s}_{0}$, tetapi tidak berbeda nyata dengan perlakuan $s_{1}$. Perlakuan $s_{2}$ berbeda nyata dengan perlakuan $\mathrm{s}_{1}$ dan $\mathrm{s}_{0}$. Perlakuan $s_{1}$ berbeda nyata dengan perlakuan $\mathrm{s}_{0}$.

Hasil uji BNT taraf 5\% pada perlakuan pupuk bio-urine sapi (B) terhadap tinggi tanaman umur 15 hari setelah tanam menunjukkan bahwa perlakuan $b_{3}, b_{2}, b_{1}$ dan $b_{0}$ satu sama lainnya saling berbeda nyata.

Hasil uji BNT taraf 5\% pada interaksi perlakuan pupuk SP-36 dan pupuk bio-urine sapi $(\mathrm{SxB})$ terhadap tinggi tanaman umur 15 hari setelah tanam menunjukkan bahwa perlakuan $s_{3} b_{3}$ dan $s_{2} b_{3}$ saling tidak berbeda nyata, tetapi kedua perlakuan tersebut berbeda nyata dengan perlakuan $s_{1} b_{3}, s_{0} b_{3}, s_{2} b_{2}$, $\mathrm{s}_{1} \mathrm{~b}_{2}, \mathrm{~s}_{3} \mathrm{~b}_{2}, \mathrm{~s}_{2} \mathrm{~b}_{0}, \mathrm{~s}_{1} \mathrm{~b}_{0}, \mathrm{~s}_{0} \mathrm{~b}_{2}, \mathrm{~s}_{0} \mathrm{~b}_{1}, \mathrm{~s}_{2} \mathrm{~b}_{1}, \mathrm{~s}_{0} \mathrm{~b}_{0}$, $\mathrm{s}_{3} \mathrm{~b}_{0}, \mathrm{~s}_{1} \mathrm{~b}_{1}$ dan $\mathrm{s}_{3} \mathrm{~b}_{1}$. Perlakuan $\mathrm{s}_{1} \mathrm{~b}_{3}$ tidak berbeda nyata dengan perlakuan $\mathrm{s}_{0} \mathrm{~b}_{3}$, tetapi berbeda nyata dengan perlakuan $\mathrm{s}_{1} \mathrm{~b}_{2}, \mathrm{~s}_{3} \mathrm{~b}_{2}, \mathrm{~s}_{2} \mathrm{~b}_{0}, \mathrm{~s}_{1} \mathrm{~b}_{0}, \mathrm{~s}_{0} \mathrm{~b}_{2}, \mathrm{~s}_{0} \mathrm{~b}_{1}, \mathrm{~s}_{2} \mathrm{~b}_{1}, \mathrm{~s}_{0} \mathrm{~b}_{0}$, $\mathrm{s}_{3} \mathrm{~b}_{0}, \mathrm{~s}_{1} \mathrm{~b}_{1}$ dan $\mathrm{s}_{3} \mathrm{~b}_{1}$. Perlakuan $\mathrm{s}_{0} \mathrm{~b}_{3}, \mathrm{~s}_{2} \mathrm{~b}_{2}$ dan $s_{1} b_{2}$ saling tidak berbeda nyata, tetapi ketiga perlakuan tersebut berbeda nyata dengan perlakuan $s_{3} b_{2}, s_{2} b_{0}, s_{1} b_{0}, s_{0} b_{2}$, $\mathrm{s}_{0} \mathrm{~b}_{1}, \quad \mathrm{~s}_{2} \mathrm{~b}_{1}, \quad \mathrm{~s}_{0} \mathrm{~b}_{0}, \quad \mathrm{~s}_{3} \mathrm{~b}_{0}, \quad \mathrm{~s}_{1} \mathrm{~b}_{1}$ dan $\mathrm{s}_{3} \mathrm{~b}_{1}$. Perlakuan $s_{3} b_{2}$ dan $s_{2} b_{0}$ tidak berbeda nyata dengan perlakuan $s_{1} b_{0}$, tetapi kedua perlakuan tersebut berbeda nyata dengan perlakuan, $s_{0} b_{2}, s_{0} b_{1}, s_{2} b_{1}, s_{0} b_{0}, s_{3} b_{0}, s_{1} b_{1}$ dan $s_{3} b_{1}$. Perlakuan $s_{1} b_{0}, s_{0} b_{2}, s_{0} b_{1}, s_{2} b_{1}$, $\mathrm{s}_{0} \mathrm{~b}_{0}, \mathrm{~s}_{3} \mathrm{~b}_{0}, \mathrm{~s}_{1} \mathrm{~b}_{1}$ dan $\mathrm{s}_{3} \mathrm{~b}_{1}$ saling tidak berbeda nyata satu sama lainnya.

\section{Tinggi Tanaman Umur 30 Hari Setelah} Tanam

Hasil sidik ragam menunjukkan bahwa perlakuan pupuk SP-36 (S) dan pupuk bio-urine sapi (B) berpengaruh sangat nyata, sedangkan interaksinya $(\mathrm{SxB})$ tidak berpengaruh nyata terhadap tinggi tanaman umur 30 hari setelah tanam 
Hasil uji BNT taraf 5\% pada perlakuan pupuk SP-36 (S) terhadap tinggi tanaman umur 30 hari setelah tanam menunjukkan bahwa perlakuan $s_{3}$ tidak berbeda nyata dengan perlakuan $s_{2}$ dan $s_{1}$, tetapi berbeda nyata dengan perlakuan $\mathrm{s}_{0}$. Perlakuan $\mathrm{s}_{2}$ tidak berbeda nyata dengan perlakuan $\mathrm{s}_{1}$, tetapi berbeda nyata dengan perlakuan $s_{0}$. Perlakuan $s_{1}$ tidak berbeda nyata dengan perlakuan $\mathrm{s}_{0}$.

Hasil uji BNT taraf 5\% pada perlakuan pupuk bio-urine sapi (B) terhadap tinggi tanaman umur 30 hari setelah tanam menunjukkan bahwa perlakuan $b_{3}$ berbeda nyata dengan perlakuan $b_{2}, b_{1}$ dan $b_{0}$. Perlakuan $b_{2}$ tidak berbeda nyata dengan perlakuan $b_{1}$, tetapi berbeda nyata dengan perlakuan $b_{0}$. Perlakuan $b_{1}$ berbeda nyata dengan perlakuan $b_{0}$.

TinggiTanamanUmur 45 Hari Setelah Tanam

Hasil sidik ragam menunjukkan bahwa perlakuan pupuk SP-36 (S) dan pupuk bio-urine sapi (B) berpengaruh sangat nyata, sedangkan interaksinya $(\mathrm{SxB})$ tidak berpengaruh nyata terhadap tinggi tanaman umur 45 hari setelah tanam.

Hasil uji BNT taraf 5\% pada perlakuan pupuk SP-36 (S) terhadap tinggi tanaman umur 45 hari setelah tanam menunjukkan bahwa perlakuan $\mathrm{s}_{3}$, $\mathrm{s}_{2}$ dan $\mathrm{s}_{1}$, saling tidak berbdeda nyata, tetapi ketiga perlakuan tersebut berbeda nyata dengan perlakuan $\mathrm{s}_{0}$.

Hasil uji BNT taraf 5\% pada perlakuan pupuk bio-urine sapi (B) terhadap tinggi tanaman umur 45 hari setelah tanam menunjukkan bahwa perlakuan $b_{3}$ berbeda nyata dengan perlakuan $b_{2}, b_{1}$ dan $b_{0}$. Perlakuan $b_{2}$ tidak berbeda nyata dengan perlakuan $b_{1}$, tetapi berbeda nyata dengan perlakuan $b_{0}$. Perlakuan $b_{1}$ berbeda nyata dengan perlakuan $b_{0}$.

\subsection{Umur Saat Berbunga (hari)}

Hasil sidik ragam menunjukkan bahwa perlakuan pupuk SP-36 (S) dan pupuk bio-urine sapi (B) berpengaruh sangat nyata, sedangkan interaksinya $(\mathrm{SxB})$ tidak berpengaruh nyata terhadap umur saat berbunga.

Hasil uji BNT taraf 5\% pada perlakuan pupuk SP-36 (S) terhadap umur saat berbunga menunjukkan bahwa perlakuan $s_{3}$ tidak berbeda nyata dengan perlakuan $s_{2}$, tetapi berbeda dengan perlakuan $s_{1}$ dan $s_{0}$. Perlakuan $s_{2}$ tidak berbeda nyata dengan perlakuan $\mathrm{s}_{1}$, tetapi berbeda nyata dengan perlakuan $\mathrm{s}_{0}$. Perlakuan $s_{1}$ tidak berbeda nyata dengan perlakuan $\mathrm{s}_{0}$.

Hasil uji BNT taraf 5\% pada perlakuan pupuk bio-urine sapi (B) terhadap umur saat berbunga menunjukkan bahwa perlakuan $b_{3}$ tidak berbeda nyata dengan perlakuan $b_{2}$, tetapi berbeda nyata dengan perlakuan $b_{1}$ dan $b_{0}$. Perlakuan $b_{2}$ tidak berbeda nyata dengan perlakuan $b_{1}$, tetapi berbeda nyata dengan perlakuan $b_{0}$. Perlakuan $b_{1}$ berbeda nyata dengan perlakuan $b_{0}$.

\subsection{Umur Saat Panen (hari)}

Hasil sidik ragam menunjukkan bahwa perlakuan pupuk SP-36 (S) dan pupuk bio-urine sapi (B) berpengaruh sangat nyata, sedangkan interaksinya (SxB) tidak berpengaruh nyata terhadap umur saat panen.

Hasil uji BNT taraf $5 \%$ pada perlakuan pupuk SP-36 (S) terhadap umur saat panen menunjukkan bahwa perlakuan $s_{3}$ tidak berbeda nyata dengan perlakuan $s_{2}$, tetapi berbeda nyata dengan perlakuan $\mathrm{s}_{1}$ dan $\mathrm{s}_{0}$. Perlakuan $\mathrm{s}_{2}$ tidak berbeda nyata dengan perlakuan $\mathrm{s}_{1}$ dan $\mathrm{s}_{0}$.

Hasil uji BNT taraf 5\% pada perlakuan pupuk bio-urine sapi (B) terhadap umur saat panen menunjukkan bahwa perlakuan $b_{3}, b_{2}, b_{1}$ dan $b_{0}$ satu sama lainnya saling berbeda nyata. 


\subsection{Jumlah Buah Per Tanaman (buah)}

Hasil sidik ragam menunjukkan bahwa perlakuan pupuk SP-36 (S) dan pupuk bio-urine sapi (B) berpengaruh sangat nyata, sedangkan interaksinya (SxB) tidak berpengaruh nyata terhadap jumlah buah per tanaman.

Hasil uji BNT taraf 5\% pada perlakuan pupuk SP-36 (S) terhadap jumlah buah per tanam menunjukkan bahwa perlakuan $s_{3}, s_{2}$ dan $s_{1}$, saling tidak berbdeda nyata, tetapi ketiga perlakuan tersebut berbeda nyata dengan perlakuan $\mathrm{s}_{0}$.

Hasil uji BNT taraf 5\% pada perlakuan pupuk bio-urine sapi (B) terhadap jumlah buah per tanaman menunjukkan bahwa perlakuan $b_{3}, b_{2}, b_{1}$ dan $b_{0}$ satu sama lainnya saling berbeda nyata.

\subsection{Berat Buah Per Tanaman (kg)}

Hasil sidik ragam menunjukkan bahwa perlakuan pupuk SP-36 (S) berpengaruh sangat nyata, perlakuan pupuk bio-urine sapi (B) berpengaruh nyata, dan interaksinya $(\mathrm{SxB})$ berpengaruh sangat nyata terhadap berat buah per tanaman.

Hasil uji BNT taraf 5\% pada perlakuan pupuk SP-36 (S) terhadap berat buah per tanaman menunjukkan bahwa perlakuan $\mathrm{s}_{3}$ berbda nyata dengan perlakuan $s_{2}$ dan $s_{0}$, tapi tidak berbeda nyata dengan perlakuan $s_{1}$. Perlakuan $s_{2}$ tidak berbeda nyata dengan perlakuan $s_{1}$ dan $\mathrm{s}_{0}$.

Hasil uji BNT taraf 5\% pada perlakuan pupuk bio-urine sapi (B) terhadap berat buah per tanaman menunjukkan bahwa perlakuan $b_{3}$ berbeda nyata dengan perlakuan $b_{2}, b_{1}$ dan $b_{0}$. Perlakuan $b_{2}$ tidak berbeda nyata dengan perlakuan $b_{1}$, tetapi berbeda nyata dengan perlakuan $b_{0}$. Perlakuan $b_{1}$ berbeda nyata dengan perlakuan $b_{0}$.

Hasil uji BNT taraf 5\% pada interaksi perlakuan pupuk SP-36 dan pupuk bio-urine sapi $(\mathrm{SxB})$ terhadap berat buah per tanaman menunjukkan bahwa perlakuan $\mathrm{s}_{3} \mathrm{~b}_{2}$ dan $\mathrm{s}_{0} \mathrm{~b}_{3}$ tidak berbeda nyata dengan perlakuan $s_{1} b_{3}, s_{2} b_{3}$ dan $s_{3} b_{3}$, tetapi berbeda nyata dengan perlakuan $s_{1} b_{2}, s_{2} b_{1}, s_{0} b_{1}, s_{2} b_{2}, s_{1} b_{1}, s_{3} b_{1}$, $\mathrm{s}_{0} \mathrm{~b}_{2}, \mathrm{~s}_{3} \mathrm{~b}_{0}, \mathrm{~s}_{2} \mathrm{~b}_{0}, \mathrm{~s}_{1} \mathrm{~b}_{0}$ dan $\mathrm{s}_{0} \mathrm{~b}_{0}$. Perlakuan $\mathrm{s}_{1} \mathrm{~b}_{3}$ tidak berbeda nyata dengan perlakuan $s_{2} b_{3}, \quad s_{3} b_{3}$ dan $s_{1} b_{2}$, tetapi berbeda nyata dengan perlakuan $\mathrm{s}_{2} \mathrm{~b}_{1}$, $\mathrm{s}_{0} \mathrm{~b}_{1}, \mathrm{~s}_{2} \mathrm{~b}_{2}, \mathrm{~s}_{1} \mathrm{~b}_{1}, \mathrm{~s}_{3} \mathrm{~b}_{1}, \mathrm{~s}_{0} \mathrm{~b}_{2}, \mathrm{~s}_{3} \mathrm{~b}_{0}, \mathrm{~s}_{2} \mathrm{~b}_{0}, \mathrm{~s}_{1} \mathrm{~b}_{0}$ dan $s_{0} b_{0}$. Perlakuan $s_{2} b_{3}$ tidak berbeda nyata dengan perlakuan $s_{3} b_{3}, s_{1} b_{2}$ dan $\mathrm{s}_{2} \mathrm{~b}_{1}$, tetapi berbeda nyata dengan perlakuan $s_{0} b_{1}, s_{2} b_{2}, s_{1} b_{1}, s_{3} b_{1}, s_{0} b_{2}, s_{3} b_{0}$, $\mathrm{s}_{2} \mathrm{~b}_{0}, \mathrm{~s}_{1} \mathrm{~b}_{0}$ dan $\mathrm{s}_{0} \mathrm{~b}_{0}$. Perlakuan $\mathrm{s}_{3} \mathrm{~b}_{3}$ tidak berbeda nyata dengan perlakuan $\mathrm{s}_{1} \mathrm{~b}_{2}$, $\mathrm{s}_{2} \mathrm{~b}_{1}, \mathrm{~s}_{0} \mathrm{~b}_{1}, \mathrm{~s}_{2} \mathrm{~b}_{2}, \mathrm{~s}_{1} \mathrm{~b}_{1}, \mathrm{~s}_{3} \mathrm{~b}_{1}$, tetapi berbeda nyata dengan perlakuan, $s_{0} b_{2}, s_{3} b_{0}, s_{2} b_{0}$, $\mathrm{s}_{1} \mathrm{~b}_{0}$ dan $\mathrm{s}_{0} \mathrm{~b}_{0}$. Perlakuan $\mathrm{s}_{1} \mathrm{~b}_{2}$ tidak berbeda nyata dengan perlakuan $\mathrm{s}_{2} \mathrm{~b}_{1}$, $\mathrm{s}_{0} \mathrm{~b}_{1}, \mathrm{~s}_{2} \mathrm{~b}_{2}, \mathrm{~s}_{1} \mathrm{~b}_{1}$ dan $\mathrm{s}_{3} \mathrm{~b}_{1}$, tetapi berbeda nyata dengan perlakuan $s_{0} b_{2}, s_{3} b_{0}, s_{2} b_{0}$, $\mathrm{s}_{1} \mathrm{~b}_{0}$ dan $\mathrm{s}_{0} \mathrm{~b}_{0}$. Perlakuan $\mathrm{s}_{2} \mathrm{~b}_{1}$ tidak berbeda nyata dengan perlakuan $\mathrm{s}_{0} \mathrm{~b}_{1}$, $s_{2} b_{2}, s_{1} b_{1}$ dan $s_{3} b_{1}$, tetapi berbeda nyata dengan perlakuan $\mathrm{s}_{0} \mathrm{~b}_{2}, \mathrm{~s}_{3} \mathrm{~b}_{0}, \mathrm{~s}_{2} \mathrm{~b}_{0}, \mathrm{~s}_{1} \mathrm{~b}_{0}$ dan $\mathrm{s}_{0} \mathrm{~b}_{0}$. Perlakuan $\mathrm{s}_{0} \mathrm{~b}_{1}, \mathrm{~s}_{2} \mathrm{~b}_{2}, \mathrm{~s}_{1} \mathrm{~b}_{1}$ dan $\mathrm{s}_{3} \mathrm{~b}_{1}$ tidak berbeda nyata dengan perlakuan $\mathrm{s}_{0} \mathrm{~b}_{2}$ dan $\mathrm{s}_{3} \mathrm{~b}_{0}$, tetapi berbeda nyata dengan perlakuan $s_{2} b_{0}, s_{1} b_{0}$ dan $s_{0} b_{0}$. Perlakuan $\mathrm{s}_{0} \mathrm{~b}_{2}$ dan $\mathrm{s}_{3} \mathrm{~b}_{0}$ tidak berbeda nyata dengan perlakuan $s_{2} b_{0}$ dan $s_{1} b_{0}$, tetapi berbeda nyata dengan perlakuan $s_{0} b_{0}$. Perlakuan $s_{2} b_{0}, s_{1} b_{0}$ dan $s_{0} b_{0}$ satu sama lainnya saling tidak berbeda nyata. 
Tabel 1. Rekapitulasi Hasil Penelitian Pengaruh PupukSP-36 dan Pupuk Bio-Urine Sapi serta Interaksinya terhadap Pertumbuhan Dan Hasil Tanaman Terong Hijau (Solanum melongena L.) Varietas Arya Hijau

\begin{tabular}{|c|c|c|c|c|c|c|c|}
\hline \multirow{2}{*}{ Faktor Perlakuan } & \multicolumn{3}{|c|}{ Tinggi Tanaman (cm) } & \multirow{2}{*}{$\begin{array}{c}\text { Umur } \\
\text { Berbunga } \\
\text { (hari) }\end{array}$} & \multirow{2}{*}{$\begin{array}{l}\text { Umur } \\
\text { Panen } \\
\text { (hari) }\end{array}$} & \multirow{2}{*}{$\begin{array}{l}\text { Jumlah } \\
\text { Buah Per } \\
\text { Tanaman } \\
\text { (buah) }\end{array}$} & \multirow{2}{*}{$\begin{array}{c}\text { Berat Buah } \\
\text { Per } \\
\text { Tanaman } \\
(\mathrm{kg})\end{array}$} \\
\hline & $15 \mathrm{HST}$ & $30 \mathrm{HST}$ & $45 \mathrm{HST}$ & & & & \\
\hline SP-36 (S) & $* *$ & $* *$ & $* *$ & $* *$ & $* *$ & $* *$ & $* *$ \\
\hline 0 ton/ha $\left(\mathrm{s}_{0}\right)$ & $8,67 \mathrm{c}$ & $21,54 \mathrm{~b}$ & $38,08 \mathrm{~b}$ & $31,29 \mathrm{a}$ & $44,22 \mathrm{a}$ & $9,75 \mathrm{~b}$ & $1,58 \mathrm{~b}$ \\
\hline 0,2 ton $/$ ha $\left(s_{1}\right)$ & $9,01 \mathrm{~b}$ & $22,06 \mathrm{ab}$ & $39,18 \mathrm{a}$ & $31,86 \mathrm{ab}$ & $44,61 \mathrm{a}$ & $11,25 \mathrm{a}$ & $1,70 \mathrm{ab}$ \\
\hline 0,3 ton/ha $\left(s_{2}\right)$ & $9,25 \mathrm{a}$ & $22,59 \mathrm{a}$ & $39,53 \mathrm{a}$ & $32,42 \mathrm{bc}$ & $45,03 \mathrm{ab}$ & $11,38 \mathrm{a}$ & $1,65 \mathrm{~b}$ \\
\hline 0,4 ton $/ \mathrm{ha}\left(\mathrm{s}_{3}\right)$ & $8,93 \mathrm{~b}$ & $22,18 \mathrm{a}$ & $39,31 \mathrm{a}$ & $32,82 \mathrm{c}$ & $44,71 \mathrm{~b}$ & $11,81 \mathrm{a}$ & $1,81 \mathrm{a}$ \\
\hline Bio-Urine Sapi (B) & $* *$ & $* *$ & $* *$ & $* *$ & $* *$ & $* *$ & $*$ \\
\hline $0 \mathrm{ml} /$ air $\left(\mathrm{b}_{0}\right)$ & $8,43 \mathrm{c}$ & $21,45 \mathrm{c}$ & $37,53 \mathrm{c}$ & $31,46 \mathrm{a}$ & $43,02 \mathrm{a}$ & $8,56 \mathrm{~d}$ & $1,14 \mathrm{c}$ \\
\hline $54 \mathrm{ml} / \tan \left(\mathrm{b}_{1}\right)$ & $8,22 \mathrm{~d}$ & $22,02 \mathrm{~b}$ & $38,73 \mathrm{~b}$ & $31,65 \mathrm{~b}$ & $44,02 \mathrm{~b}$ & $10,44 \mathrm{c}$ & $1,69 \mathrm{~b}$ \\
\hline $64 \mathrm{ml} / \tan \left(\mathrm{b}_{2}\right)$ & $9,05 \mathrm{~b}$ & $22,09 \mathrm{~b}$ & $38,98 \mathrm{~b}$ & $32,29 \mathrm{bc}$ & $45,43 \mathrm{c}$ & $11,44 \mathrm{~b}$ & $1,80 \mathrm{~b}$ \\
\hline $74 \mathrm{ml} / \tan \left(\mathrm{b}_{3}\right)$ & $10,16 \mathrm{a}$ & $22,80 \mathrm{a}$ & $40,86 \mathrm{a}$ & $32,98 \mathrm{c}$ & $46,11 \mathrm{~d}$ & $13,75 \mathrm{a}$ & $2,11 \mathrm{a}$ \\
\hline Interaksi $(\mathrm{SxB})$ & $* *$ & tn & tn & tn & tn & tn & $* *$ \\
\hline $\mathrm{s}_{0} \mathrm{~b}_{0}$ & $8,24 \mathrm{e}$ & 21,13 & 37,09 & 30,25 & 43,15 & 7,75 & $1,00 \mathrm{~g}$ \\
\hline $\mathrm{s}_{0} \mathrm{~b}_{1}$ & $8,31 \mathrm{e}$ & 21,30 & 37,63 & 30,77 & 42,97 & 9,50 & $1,68 \mathrm{de}$ \\
\hline $\mathrm{s}_{0} \mathrm{~b}_{2}$ & 8,34 e & 21,45 & 37,48 & 31,93 & 44,97 & 9,75 & 1,39 ef \\
\hline $\mathrm{s}_{0} \mathrm{~b}_{3}$ & $9,80 \mathrm{bc}$ & 22,30 & 40,13 & 32,20 & 45,82 & 12,00 & $2,25 \mathrm{a}$ \\
\hline $\mathrm{s}_{1} \mathrm{~b}_{0}$ & $8,48 \mathrm{de}$ & 21,31 & 37,24 & 30,85 & 43,05 & 8,75 & $1,09 \mathrm{fg}$ \\
\hline $\mathrm{s}_{1} \mathrm{~b}_{1}$ & 8,22 e & 22,20 & 39,24 & 31,50 & 44,13 & 9,25 & $1,65 \mathrm{de}$ \\
\hline $\mathrm{s}_{1} \mathrm{~b}_{2}$ & $9,46 \mathrm{c}$ & 22,10 & 39,17 & 32,25 & 45,25 & 12,50 & $1,91 \mathrm{bcd}$ \\
\hline $\mathrm{s}_{1} \mathrm{~b}_{3}$ & $9,88 \mathrm{~b}$ & 22,64 & 41,07 & 32,83 & 46,00 & 14,50 & $2,16 \mathrm{ab}$ \\
\hline $\mathrm{s}_{2} \mathrm{~b}_{0}$ & $8,78 \mathrm{~d}$ & 21,75 & 37,84 & 33,03 & 42,98 & 8,25 & $1.10 \mathrm{fg}$ \\
\hline $\mathrm{s}_{2} \mathrm{~b}_{1}$ & $8,24 \mathrm{e}$ & 22,41 & 38,99 & 31,56 & 45,05 & 11,50 & $1,77 \mathrm{~cd}$ \\
\hline $\mathrm{s}_{2} \mathrm{~b}_{2}$ & $9,61 \mathrm{c}$ & 22,84 & 40,06 & 32,07 & 45,82 & 11,75 & $1,65 \mathrm{de}$ \\
\hline $\mathrm{s}_{2} \mathrm{~b}_{3}$ & $10,39 \mathrm{a}$ & 23,37 & 41,24 & 33,03 & 46,28 & 14,00 & $2,07 \mathrm{abc}$ \\
\hline $\mathrm{s}_{3} \mathrm{~b}_{0}$ & 8,24 e & 21,62 & 37,95 & 31,70 & 42,89 & 9,50 & 1,39 ef \\
\hline $\mathrm{s}_{3} \mathrm{~b}_{1}$ & $8,11 \mathrm{e}$ & 22,20 & 39,06 & 32,77 & 43,93 & 11.50 & $1,64 \mathrm{de}$ \\
\hline $\mathrm{s}_{3} \mathrm{~b}_{2}$ & $8,78 \mathrm{~d}$ & 21,99 & 39,23 & 32,93 & 45.68 & 11,75 & $2,25 \mathrm{a}$ \\
\hline $\mathrm{s}_{3} \mathrm{~b}_{3}$ & $10,58 \mathrm{a}$ & 22,90 & 41,00 & 33,88 & 46,36 & 14,50 & $1,95 \mathrm{abcd}$ \\
\hline
\end{tabular}

Keterangan :

tn $=$ berpengaruh tidak nyata

$*$ = berpengaruh nyata

$* *$ = berpengaruh sangat nyata

HST = hari setelah tanam.

Pengaruh Pupuk SP-36 Terhadap Pertumbuhan dan Hasil Tanaman Terong Hijau (Solanum Melongena L.) Varietas Arya Hijau. Hasil sidik ragam menunjukkan bahwa perlakuan pupuk SP-36 (S) berpengaruh sangat nyata terhadap tinggi tanaman umur 15 hari, 30 hari dan 45 hari setelah tanam, umur berbunga, umur panen, jumlah buah per tanaman dan berat buah per tanaman.

Perlakuan pupuk SP-36 berdasarkan hasil sidik ragam pada pertumbuhan tanaman terong hijau, yaitu tinggi tanaman umur 15 hari, umur 30 hari dan 45 hari setelah tanam. Terdapat perbedaan yang nyata satu sama lainnya. Hal ini menunjukkan bahwa perlakuan pemberian pupuk SP-36 dapat meningkatkan unsur hara bagi tanaman, pupuk SP-36 mampu meningkatkan kesuburan tanah dan meningkatkan aktifitas mikroba tanah. Karena berdasarkan hasil analisis tanah di media polibag sebelum penanaman, $\mathrm{pH}$ nya tergolong agak masam $(\mathrm{pH} \mathrm{5,60),} \mathrm{C}$ 
organik rendah $(1,87), \mathrm{C} / \mathrm{N}$ rasio sedang $(7,93), \mathrm{N}$ total sedang $(0,24), \mathrm{P}$ tersedia sangat rendah $(1,75), \mathrm{K}$ tersedia tinggi $(64,07)$, Kation Basa $\mathrm{Ca}^{++}$sangat rendah $(1,65), \mathrm{Mg}^{++}$rendah $(0,64), \mathrm{K}^{++}$sedang $(0,52), \mathrm{Na}^{++}$rendah $(0,37)$, KTK rendah $(6,39)$ dan kejenuhan basa sedang $(49,8)$. Hal ini menggambarkan bahwa ketersediaan unsur hara makro N, P dan $\mathrm{K}$ yang ada di dalam tanah masih cukup rendah, sehigga perlu ditambah. Terutama pemupukan dengan menggunakan pupuk SP-36 yang mengandung unsur hara makro dan unsur hara mikro. Karena ketersediaan unsur hara dalam tanah kurang mencukupi, maka dengan perlakuan pemberian pupuk SP-36 dengan berbagai dosis yang dapat direspon tanaman dengan cepat. Jumlah buah terbanyak dan berat buah terberat per tanaman terdapat pada perlakuan dosis pupuk 25,6 g/tanaman yaitu 11,81 buah/tanaman dan 1,81 kg/tanaman. Sedangkan yang terendah terdapat pada perlakuan dosis pupuk 12,8 g/tanaman yaitu 9,75 buah/tanaman dan 1.58 $\mathrm{kg} /$ tanaman. Hasil Penelitian analisa tanah di Desa Giri Agung KTK kebanyakan rendah, adapun KTK yang rendah dapat ditingkatkan dengan penggunaan pupuk organik yang berguna untuk meningkatkan tanah menjadi gembur dan daya jerap tanah dan untuk meningkatkan kapasitas tukar kation sehingga dapat menampung apabila dilakukan penambahan unsur hara baik secara alami maupun dengan penambahan pupuk (Datu BP et al. 2013). Selanjutnya pemupukan ditentukan oleh keadaan tanah seperti tanah-tanah pada lokasi studi menunjukkan reaksi tanah masam perlu dilakukan pemberian kapur (I Gede EB et al. 2017).

Pengaruh Pupuk Bio-Urine Sapi Terhadap Pertumbuhan dan Hasil Tanaman Tanaman Terong Hijau (Solanum Melongena L.) Varietas Arya
Hijau. Hasil sidik ragam menunjukkan bahwa perlakuan Pupuk Bio-Urine Sapi (B) berpengaruh sangat nyata terhadap tinggi tanaman umur 15 hari, 30 hari dan 45 hari setelah tanam, umur berbunga, umur panen, jumlah buah per tanaman. Berpengaruh nyata terhadap berat buah per tanaman.

Perlakuan Pupuk Bio-Urine Sapi berpengaruh sangat nyata pada pertumbuhan tanaman terong hijau, hal ini diduga bahwa pemberian Pupuk BioUrine Sapi mampu mempercepat penyerapan unsur hara mikro dan unsur hara makro selain itu Pupuk Bio-Urine Sapi mengandung unsur karbon dan nitrogen yang mampu mempertahankan atau memperbaiki kesuburan tanah dan kuat terhadap serangan penyakit pada tanaman terong hijau. Hasil sidik ragam menunjukkan bahwa pengaruh pemberian pupuk oganik berbeda sangat nyata terhadap umur tanaman saat berbunga dan umur tanaman saat panen tanaman terung (safei dkk., 2014).

Pada parameter lainnya seperti umur saat berbunga berpengaruh sangat nyata, umur panen, jumlah buah pertanaman. berat buah per tanaman berpengaruh nyata. Walaupun dari datadatanya terlihat ada kecenderungan terjadi peningkatan pertumbuhan tanaman terong dengan ditingkatkannya konsentrasi Pupuk Bio-Urine Sapi. Bahwa pemberian pupuk dalam tingkatan optimum dapat membantu revitalisasi produktifitas tanah dan untuk meningkatkan kualitas produk. Terdapat kecenderungan dengan semakin meningkatnya pupuk bio-urine sapi, yaitu dari konsentrasi pupuk $54 \mathrm{ml} /$ tanaman, $64 \mathrm{ml} /$ tanaman dan $74 \mathrm{ml} / \operatorname{tanaman}$ yang diberikan, maka jumlah buah dan berat buah terong semakin meningkat pula. Jumlah buah terbanyak dan berat buah terberat terdapat pada perlakuan konsentrasi pupuk bio-urine sapi 74 $\mathrm{ml} /$ tanaman, yaitu 13,75 buah/tanaman 
dan 2,11 kg/tanaman, sedangkan yang terendah terdapat pada perlakuan konsentrasi pupuk $54 \mathrm{ml} /$ tanaman yaitu 8,56 buah/tanaman dan $1,14 \mathrm{~kg} /$ tanaman. Semakin meningkat jumlah pupuk yang diberikan berarti semakin banyak tersedia unsur hara bagi tanaman, tidak merusak tanah (Hadisuwito, 2012).

Pengaruh Interaksi Perlakuan Pupuk SP-36 dan Pupuk Bio-Urine Sapi Terhadap Pertumbuhan dan Hasil Tanaman Terong Hijau (Solanum Melongena L.) Varietas Arya Hijau. Hasil sidik ragam menunjukkan bahwa interaksi perlakuan berpengaruh sangat nyata terhadap tinggi tanaman umur 15 hari setelah tanam. Berpengaruh tidak nyata terhadap tinggi tanaman umur 30 dan 45 hari setelah tanam, umur tanaman saat berbunga, umur tanaman saat panen, jumlah buah per tanaman. Berpengaruh sangat nyata terhadap berat buah per tanaman.

Jumlah buah terbanyak terdapat pada perlakuan $\mathrm{s}_{3} \mathrm{~b}_{3}$ (pupuk SP-36 dengan dosis 25,6 g/tanaman dan pupuk biourine sapi dengan konsentrasi 74 $\mathrm{ml} /$ tanaman) yaitu 11,81 buah dan 13,75 buah. Berat buah terberat terdapat pada perlakuan $\mathrm{s}_{3} \mathrm{~b}_{3}$ (pupuk SP-36 dengan dosis 25,6 g/tanaman dan pupuk biourine sapi dengan konsentrasi 74 $\mathrm{ml} /$ tanaman) yaitu $1,81 \mathrm{~kg} /$ tanaman dan $2,11 \mathrm{~kg} / \mathrm{tanaman}$. sedangkan yang terendah terdapat pada perlakuan $\mathrm{s}_{0} \mathrm{~b}_{0}$ (pupuk SP-36 dengan dosis 12,8 g/tanaman dan pupuk bio-urine sapi dengan konsentrasi $54 \mathrm{ml} /$ tanaman), yaitu 9,75 buah dan 8,56 buah. Berat buah terendah terdapat pada $\mathrm{s}_{0} \mathrm{~b}_{3}$ (pupuk SP-36 dengan dosis 12,8 g/tanaman dan pupuk bio-urine sapi dengan konsentrasi 54 $\mathrm{ml} /$ tanaman) yaitu $1,58 \mathrm{~kg} /$ tanaman dan $1,14 \mathrm{~kg} /$ tanaman. Pengamatan terhadap parameter jumlah buah per tanaman dan berat buah per tanaman lebih rendah dibandingkan dengan dekskripsi. Kondisi ini diduga karena penelitian di lakukan di polibag sehingga memberikan produksi tanaman yang kurang optimal di bandingkan dengan menanam tanaman di lapangan. Pemberian bokashi dapat meningkatkan produksi terong ungu (Raksun dan Mertha, 2018; Hendri, dkk., 2015). Pemberian pupuk kendang dan NPK meningkatkan produksi terung hijau (Yunita, dkk., 2016). Perlakuan Hal ini disebabkan bahwa pupuk pupuk SP-36 dan pupuk bio-urine sapi mempunyai unsur hara yang banyak sehingga dapat meningkatkan kesuburan tanah dan aktifitas mikroba tanah, semakin banyak unsur hara yang tersedia bagi tanaman untuk pertumbuhan vegetatif dan generatif, terutama dalam pembentukan jumlah buah per tanaman dan berat buah per tanaman (Musnamar, 2011).

\section{KESIMPULAN}

Kesimpulan dari hasil penelitian adalah sebagai berikut : Pengaruh pemberian Pupuk SP-36 terhadap pertumbuhan tanaman terong hijau varietas arya hijau berpengaruh sangat nyata terhadap tinggi tanaman umur 15 , 30 dan 45 hari setelah tanam, umur saat berbunga, umur panen, jumlah buah per tanaman dan berat buah per tanaman. Berat buah terong tertinggi terdapat pada perlakuan $\mathrm{s}_{3}$ (pupuk SP-36), yaittu 1,81 $\mathrm{kg} /$ tanaman, sedangkan yang terendah terdapat pada perlakuan $\mathrm{s}_{1}$ (pupuk SP36), yaitu $1,58 \mathrm{~kg} /$ tanaman

Pengaruh pemberian Pupuk BioUrine Sapi sangat berpengaruh nyata terhadap tinggi tanaman umur 15, 30 dan 45 hari setelah tanam, umur saat berbunga, umur panen, jumlah buah per tanaman. Berpengaruh nyata terhadap berat buah per tanaman. Berat buah terong hijau tertinggi terdapat pada perlakuan $b_{3}$ (pupuk bio-urine sapi), yaitu $2,11 \mathrm{~kg} /$ tanaman, sedangkan yang terendah terdapat pada perlakuan $b_{1}$ 
(pupuk bio-urine sapi), yaitu 1,14 $\mathrm{kg} / \mathrm{tanaman}$.

Interaksi perlakuan Pupuk SP-36 dan Pupuk Bio-Urine Sapi berpengaruh sangat nyata terhadap tinggi tanaman umur 15 hari setelah tanam. Berpengaruh tidak nyata terhadap umur 30 dan 45 hari setelah tanam, umur saat berbunga, umur panen, jumlah buah pertanaman. Berpengaruh sangat nyata terhadap berat buah per tanaman. Berat buah terong tertinggi terdapat pada perlakuan $\mathrm{s}_{3} \mathrm{~b}_{3}$ (pupuk SP-36 dengan dosis 25,6 g/tanaman dan pupuk bio-urine sapi dengan konsentrasi $74 \mathrm{ml} /$ tanaman), yaitu 1,81 dan $2,11 \mathrm{~kg} /$ tanaman, sedangkan yang terendah terdapat pada perlakuan $\mathrm{s}_{1} \mathrm{~b}_{1}$ (pupuk SP-36 dengan konsentrasi $12,8 \mathrm{~kg} /$ tanaman dan pupuk bio-urine sapi dengan dosis $54 \mathrm{ml} /$ tanaman), yaitu 1,81 dan $1,14 \mathrm{~kg} /$ tanaman.

\section{DAFTAR PUSTAKA}

Affandi, (2008). Pemanfaatan Urine Sapi yang Difermentasi sebagai Nutrisi Tanaman. Yogyakarta: Andi Offset.

Budiana, I. G. E., Jumani., Biantary, M.P. (2017). Evaluation of Soil Revegetation Success Rate Ex-Pit Coal Mine in Kitadin site Embalut Kutai in East Kalimantan. Agrifor, 16(2), 195208.

Iritani, Galuh. (2012). Vegetable Gardening : Menanam Sayuran di Pekarangan Rumah. Yogyakarta: Indonesia Tera.

Hadisuwito, S. (2012). Membuat Pupuk Organik Cair. Jakarta: Agromedia Pustaka.

Hendri, M., Napitupulu, M., \& Sujalu, A. P. (2015). Pengaruh pupuk kandang sapi dan pupuk NPK Mutiara terhadap pertumbuhan dan hasil tanaman terung ungu (Solanum melongena L.). Agrifor, 14(2), 213220.

Munawar, A. (2011). Kesuburan Tanah dan Nutrisi Tanaman. Bogor: IPB Press.

Pramana, D. B. (2013). Pertumbuhan Tanaman Gaharu (Aquilaria sp.) di Desa Giri Agung Kecamatan Sebulu Kabupaten Kutai Kartanegara Provinsi Kalimantan Timur. Agrifor, 11(2), 110-114.

Rahayu, Murni .S dan Nurhayati. (2005). Penggunaan EM4 Dalam Pengomposan Limbah Teh Padat. Medan: Fakultas Pertanian Universitas Islam Sumatra Utara.

Raksun, A., \& Mertha, I. G. (2018). Pengaruh Bokashi Terhadap Produksi Terong Ungu (Solanum melongena L.). Jurnal Biologi Tropis, 18(1), 21-26.

Safei, M., Rahmi, A., \& Jannah, N. (2014). Pengaruh Jenis Dan Dosis Pupuk Organik Terhadap Pertumbuhan Dan Hasil Tanaman Terung (Solanum melongena L.) varietas Mustang F-1. Agrifor, 13(1), 59-66.

Setiawan, B.S. (2010). Membuat Pupuk Kandang Secara Tepat, Depok: Penebar Swadaya,

Yitnosumarto, S. (1993). Percobaan, Perancangan, Analisis dan Interpretasinya. Jakarta: Gramedia.

Yuanita, V. R., Kurniastuti, T., \& Puspitorini, P. (2016). Respon Pupuk Kandang Kambing Dan Pupuk Npk Pada Pertumbuhan Dan Hasil Tanaman Terung Hijau (Solanum melongena L.). VIABEL: Jurnal Ilmiah Ilmu-Ilmu Pertanian, 10(1), 53-62. 